\title{
As Camas Hospitalares São Tão Preciosas como Escassas
}

\section{Hospital Beds Are as Precious as they are Scarce}

João Araújo Correia (https://orcid.org/0000-0002-6742-3900)

Presidente da Sociedade Portuguesa de Medicina Interna

Ficamos a saber no final de 2018 de que Portugal era o quinto País mais envelhecido do mundo, substituindo a Alemanha, numa lista liderada pelo Japão, a que se seguem a Itália, a Grécia e a Finlândia (PORDATA). Parece que em 2030, atingiremos o terceiro lugar, com uma idade média nacional de 50,2 anos.

Sempre me custou compreender a razão de não utilizarmos os factos que a estatística nos demonstra, com anos de antecipação, para adaptarmos as respostas do Sistema Nacional de Saúde (SNS). Todos sabemos que o preço da longevidade é a multimorbilidade e a dependência, que temos de combater, mas que sempre avança, seja ela de carater motor ou cognitivo. Por isso, o peso no SNS do Doente Crónico Complexo vai-se acentuando cada vez mais, traduzido em múltiplos recursos ao Serviço de Urgência e inúmeras hospitalizações, com tempos de internamento alargados.

É útil avaliar o número de camas por 100000 habitantes e verificar se este é congruente com o envelhecimento da população. Portugal, tinha 395,9 camas/100 mil em 1985, tendo em 2017 339,3/100 mil, o que merece comparação com a média dos 27 Países da União Europeia, que é de 541,4 camas/100 mil. Vale a pena referir, que a Alemanha soube ler os números, como $6^{\circ}$ País mais envelhecido do mundo, tendo 800,2 camas por 100000 habitantes, para dar resposta ás espectáveis necessidades de internamento hospitalar da sua população.

A SPMI aproveitou o dia 18/2/2020, em que fazia com a Associação dos Administradores Hospitalares (APAH) a recolha de dados para o $4^{\circ}$ Barómetro dos Internamentos Sociais, para fazer um estudo dos doentes internados com alta clínica e camas extra lotação, nos Serviços de Medicina Interna Portugueses. Responderam 70 Serviços de MI (68\%), aos quais corresponde uma lotação base de 3447 camas. Destas, 864 camas estavam ocupadas por doentes com alta clínica (25,07\%): 493 (57\%) doentes aguardavam colocação na Rede Nacional de Cuidados Continuados (RNCC), 148 (17\%) nos Cuidados Paliativos e 223 (26\%) esperavam por um Lar. Nestes números, há que acrescentar o facto do tempo de espera na RNCC ou nos CP ser inferior a 2 semanas, mas a demora média para colocação num lar supera os 6 meses! Para tornar ainda mais evidente o facto destas camas "mal ocupadas" serem muito necessárias, constatamos que os Serviços de Ml eram responsáveis nesse dia por mais 1235 camas extra (+36\%). Destas, 103 (9\%) eram camas "acrescentadas" no espaço físico dos Serviços de MI, 597 (48\%) estavam noutros Serviços e 535 (43\%) eram doentes internados no Serviço de Urgência!

É a isto que eu chamo o paradigma da incongruência! Para além de não adequarmos o número de camas hospitalares á população portuguesa, cada vez mais envelhecida e doente, damo-nos ao luxo de ter $25 \%$ das camas dos Serviços de Medicina Interna ocupadas por doentes com alta clínica. Depois, obrigamos os Internistas ao esforço adicional de serem responsáveis por mais 36\% de doentes espalhados pelo Hospital, muitos deles a permanecerem vários dias no Serviço de Urgência.

Para estarmos mais preparados para uma pandemia, que é sempre disruptiva, o SNS não pode estar sempre a trabaIhar nos limites, nas questões de material ou de pessoal. Há que corrigir estas ineficiências, para termos alguma folga nas camas e não termos os Médicos esgotados, logo no início da batalha!.

(C) Author(s) (or their employer(s)) 2019. Re-use permitted under CC BYNC. No commercial re-use.

(c) Autor (es) (ou seu (s) empregador (es)) 2019. Reutilização permitida de acordo com CC BY-NC. Nenhuma reutilização comercial.

Recebido/Received: 21/03/2020

Aceite/Accepted: 25/03/2020

Publicado / Published: 27 de Junho de 2020 